\title{
ONLINE ECONOMICS HIGHER EDUCATION DURING COVID-19, A CASE STUDY APPROACH: THE BUCHAREST UNIVERSITY OF ECONOMIC STUDIES, THE FACULTY OF BUSINESS AND TOURISM
}

\author{
Luciana-Floriana Holostencu ${ }^{1 *}$, Maria-Cristina Iorgulescu², Mădălina-Lavinia Ţală ${ }^{3}$, \\ Mădălina-Ionela Iordache ${ }^{4}$, Ileana Vălimăreanu (Mircioi) ${ }^{\mathbf{5}}$, Poida Georgiana Crina ${ }^{6}$ \\ ${ }^{I}$ Bucharest University of Economic Studies, Romania, luciana.holostencu@yahoo.ro \\ ${ }^{2}$ Bucharest University of Economic Studies, Romania, cristina.iorgulescu@com.ase.ro \\ ${ }^{3}$ Bucharest University of Economic Studies, Romania, madalina.tala@com.ase.ro \\ ${ }^{4}$ Bucharest University of Economic Studies, Romania,iordache.madalina55@yahoo.com \\ ${ }^{5}$ Bucharest University of Economic Studies, Romania, ileana.mircioi@ase.ro \\ ${ }^{6}$ Bucharest University of Economic Studies, Romania, poidageorgiana20@stud.ase.ro
}

\begin{abstract}
From what in March 2020 seemed as a simple health issue, the Covid-19 pandemic has led to a global crisis with a huge social, economic and educational impact. As a result, many countries that were not prepared for such a situation, in terms of infrastructure, had to abruptly adapt with the resources they had to their disposal at that time. For example, in Romania, most schools and universities moved their classes online via different online platforms, but students from rural areas were not able to attend school at all. The present study aims to evaluate students' perceptions and difficulties regarding online (blended) learning compared to traditional classroom attendance with a main focus on the difficulties encountered in the process of learning economic subjects. We performed a quantitative research by implementing an online questionnaire which was sent out by the end of the second semester of 2020 - 2021 school year. The respondents were freshmen from The Bucharest University of Economic Studies, The Faculty of Business and Tourism, enrolled in October 2020. Being aware that the quality of their learning might be affected via blended learning, all these respondents agreed to take part into various optional activities provided by the means of the Secondary Education Project-ROSE BT. Therefore, the current study might offer an useful insight into difficulties encountered by these students and solutions provided by both teachers and the university as an institution interested into facilitating the online education process. Moreover, the results will show possible factors that may determine difficulties into understanding various economic subjects and students' own motion for improving their situation.
\end{abstract}

Keywords:

Higher education, online learning, learning difficulties, coronavirus pandemic, educational technology

JEL Classification: A29, I21

DOI: $10.24818 / \mathrm{CTS} / 3 / 2021 / 2.03$

\section{Introduction}

At the beginning of March 2020, due to a sudden health crisis, The World Health Organization (WHO) has proclaimed a worldwide pandemic generated by a novel coronavirus SARS-CoV2 (WHO, 2020), leading to an enormous crisis with more negative consequences than those caused during The World War II (Huang et al., 2020). Based on a fast-track research, results showed that the virus can spread on a fast pace inside the community, causing irreversible damages and sudden death (Paules et al., 2020). In order to control the spread of SARS-CoV2 virus, specialists from all over the world have proposed different measures such as physical distancing and even local or national lockdowns.

As a response to the crisis, over 100 countries were forced to implement nationwide university and school closures by the end of March 2020. These measures have initially affected almost 900 million children and students all over the world (Viner et al. 2020) which, according to UNESCO will count for around $60 \%$ of the worldwide students cohort (UNESCO, 2020a) and were extended to over 1.7 billion children, youth and their families (OECD, 2020).

* contact author 
As a result, the measures of compulsory physical distancing have been adopted by governments worldwide, including Romania, which abruptly turned out into a nationwide university, school, kindergarten and other academic institutions' closure and the forced and sudden implementation of Elearning or online distance learning (Edelhauser and Lupu-Dima, 2020). Not only in Romania, but worldwide, universities were not expecting such a sudden transition from the traditional classroom education to online distance education, as a result, many were missing the hardware and software support, but also strategies in order to adapt and continue in an emergency setup (Zhang, Wang, Yang, \& Wang, 2020).

Even though in the last 20 years, the technology used in formal and informal education has notably been evolving, many universities were taken by surprise and had to comply to existing solutions which, in the end, proved to be more effective than expected (Dhawan, 2020; Chakraborty et. al, 2021). Besides the validated online platforms such as The Bucharest University of Economic Studies blended platform, teachers and students decided to adapt and use more colloquial applications such as Discord and WhatsApp (Nash, 2020) which mitigated the short-term effects of the crisis. Nonetheless, all the parties involved in the educational process (professor, student, institution and other operational staff) had to face a gargantuan range of technical, financial and even economic or social problems (Peters et al., 2020). Moreover, many studies have proven that lockdown and the idea of an ongoing pandemic have negatively determined mental health issues for students and professors, such as stress, depression and anxiety (Cao et al., 2020) that, in many cases came as a burden for both parties into adapting to an online distance learning system due to lack of technical expertise and, therefore, creating a profound division between tech-savvies and those reluctant to technology (Jæger \& Blaabæk, 2020).

As a result, we carried out the current research in order to investigate The Faculty of Business and Tourism's freshmen difficulties encountered in distance online learning, their solutions to ease and make the process of learning more pleasant, their preferences between classical and online learning and potential factors (e.g. academic or technical obstacles) that might lead them to consider a potential university dropout. Moreover, the paper is a result of a common effort implemented during the 20202021 academic year by a group of professors, business specialists and students during a common effort called From university dropout to performance in Business and Tourism (Perform-BT), financially supported via the Grant Scheme for Universities and materialized under the Secondary Education Project - ROSE ${ }^{1}$. The main desired outcome of the analysis is to find and generate sufficient details for a framework that might be used by both professors and students in order to ease the learning process and to record as many academic performances as possible, especially for freshmen enrolled at the aforementioned faculty.

\section{Literature review}

The phenomenon of digital transformation has been intensely discussed in the last three decades and it has often been correlated to higher education and improved results in academia from both a student's and a professor's angle (Kopp et al., 2019).

Even though the concept of online learning was considered a nice-to-have academic benefit or alternative in academia years ago, there were little to no universities that made a strategy for implementing such a distance learning model, in order to assure stability in educational activities (Ribeiro, 2020). After WHO's announcement, in the spring of 2020 that, in order to be safe we must respect a policy of social distancing in public places many universities followed suit and abruptly closed their doors (Bao, 2020), activating an emergency plan of adapting the educational process by using basic digital and communication platforms (Babatunde, Adedoyin and Soykan, 2020) and, therefore, causing a sudden disruption of the classical teaching and learning workflow.

Most of the academic institutions did not have the opportunity to think through their strategy and the possibility of creating or integrating new solutions (Carroll and Conboy, 2020) on existing platforms such as the Online Blended Learning Platform provided and updated by The Bucharest University of Economic Studies.

\footnotetext{
${ }^{1}$ AG nr. 174 /SGU/NC/II din 10.09.2019
} 
Therefore, the Covid-19 pandemic literally pushed the process of digital transformation of higher education, and as a result, measures and ideas that usually took years to make possible because of reasons such as bureaucracy or management decisions, were suddenly presented and implemented in a matter of weeks, if not days, creating online distance learning the new roaring innovation in academia (Strielkowski, 2020).

Moreover in accordance to this worldwide policy of social distancing, economic academic institutions were compelled to make appropriate and prompt adjustments in order to assure a steady flow in education and to further academic progress by providing all the necessary tools to the main affected stakeholders, students and professors. Therefore, all educational activities were immediately shifted to a full E-learning framework, with specific obstacles along the way (Amir et al., 2020).

Online learning or E-learning represents the use of internet and other applications and hardware to create educational materials and to deliver them on the basis of a specific curriculum, timetable or even framework (Fry, 2001). According to Hrastinski (2008) nowadays we have two main categories of online learning: synchronous and asynchronous online learning. In Romania, the first was implemented initially by using communication applications such as Discord, WhatsApp or Skype and was later on extended to video learning using Zoom Meeting, Google Meet or Microsoft Teams. The second was used mostly by universities that had an internal application such as the Blended Learning Platform where students and teachers exchanged ideas, uploaded materials and were sending various individual or group projects. In addition, previous research has shown that blended learning provides better student's motivation, satisfaction, engagement with peers and professors and therefore, better academic performance (Garrison and Kanuka, 2004; Poon, 2013).

In order to leave up to their objectives, universities had to incorporate the aforementioned technological and innovative strategies that, for sure have changed the learning context for good (Hodges et al., 2020). Moreover, previous data has depicted that E-learning and online tools are both effective for teaching and learning in various areas of academic interest, including economic research (Toprak et al., 2021). In addition, we found a few studies that presented students' performance and learning processes as equivalent (quality-wise) to classical teaching and interaction (Zogas et al., 2016; Pei and Wu, 2019).

Considering the crisis response of students, the faculty and professors, the process of education must also be analyzed in relation to each individual's level of digital expertise and the amount of information available for acquiring such skills. For example, while generation $\mathrm{Z}$ students and some professors have digital skills or consider themselves as native users of ITC (Prensky, 2001), there are others who don't have neither the skills nor the infrastructure to learn or the economic possibility to do so (Bennett et al., 2008).

As Shariman et al. (2012) explained, students from developing countries such as Romania encounter various difficulties in a process of distance learning, starting from lack of hardware, to lack of abilities and help from the government or even the university itself. In a similar situation can also be found their teachers. This way, while for some learning online is efficient and pleasant, for others might easily become a burden.

The fight against Covid-19 pandemic has brought to surface even more fractures of the education system (Bozkurt \& Sharma, 2020). As Ribeiro (2020) has rightly remarked, this present jump to a digital era of learning and information delivery materialized various challenges and attitudinal alterations. According to Feldman (2020) there are a few measures to be taken into consideration, such as: (i) the importance of a relaxed atmosphere on academic performance; (ii) paying attention to people that could be affected from racial or economic disparities, (iii) first make sure that teachers are well instructed in order to have better instructed students; (iv) make sure to use only pass or incomplete grades. Therefore, difficult times must consider different and innovative measures in order to keep the students interested into learning, even though the process of instruction is entirely online.

Physical university closures and online distance education, synchronous or asynchronous, still may have a negative impact over students' learning from other angles worth of our consideration, such as: assigning a shorter time for learning with no focus, additional stress or boredom, a change in the process of peer-to-peer interaction and student-professor communication, and, in the end, the lack of learning 
motivation which might lead to the bigger problem of considering dropping out as a valid option. (Di Pietro et al., 2020).

As other researchers (Bojovic et al., 2020; Patricia; 2020) have tried to understand the difficulties encountered by students in relation to online education during the COVID-19 crisis using empirical data, we will also try to find problems and even solutions from students, mainly for their academic improved performance that might be translated into tips and tricks for their professors.

Moreover, in the face of reports that compare classroom attendance to distance learning, the analysis of a student-centered education, delivered via blended learning methods or synchronous techniques has yet to be deeply analyzed. In our opinion a student anonymous feedback may bring forth crucial information for the evaluation of online learning during COVID-19 with the main objective of improving future learning strategies and reducing as much as possible the freshmen dropout rate, creating new opportunities of development for all the educational process stakeholders. Also, the present research may bring additional value to the existing body of research on the current subject.

\section{Methodology}

\subsection{Case description}

As part of The Bucharest University of Economic Studies' most preeminent faculties, The Faculty of Business and Tourism is one of Romania's best performing academic institutions in economic higher education for over seven decades. By providing a wide range of programs, from bachelor's to doctoral and postgraduate programs its mission is training the best specialists in business administration, commerce, services, tourism and quality management. Moreover, the teaching body is focused on the long-term and extended approach of refining and adapting academic information via lectures, articles, books or seminars, along with implementing up to date research and teaching methodologies in order to ease a student's effort into understanding and assimilating a particular subject.

Before the official global announcement of the Covid-19 pandemic, as any European university following the Bologna system of education, The Faculty of Business and Tourism provided students with subjects delivered via classroom learning and interaction, both in terms of lectures and seminars, with the contractual constraint for students of being present on campus premises. Since March 2020, the institution made sure to innovate and adapt its blended learning system which consisted in the use of both synchronous and asynchronous activities, depending on the difficulty of the subject and students' preferences regarding a common approach agreed with the professor. By implementing applications such as Zoom Meetings or Google Meet to lectures and a consistent part of seminars, the main objective was to simulate the traditional attendance of both creating group or individual activities and providing a student-centered methodology that encourages collaboration between peers.

On one side, as in a classroom learning set the lecture attendance reached $60-70 \%$ of enrolled students, distance learning via Zoom Meetings dropped with almost $50 \%$ or worse. On the other side, the seminar attendance has grown, giving students the possibility to gains extra-credit that on a tradition learning framework would not have happened. Apart from alterations regarding participants' attendance, the subjects and their content were kept according to the curriculum with the required updates specific to an academic environment, being presented in weekly units in order to be assimilated as easily as possible by students. Each interactive seminar used as main information the lecture provided the week before. Lectures were held $100 \%$ live via Zoom or Google Meet, while seminars were adapted to student's needs and requirements. The blended learning platform was used in both cases and also became the main interface for communicating and even taking the exams or uploading assignments. Communication with students was encouraged by teachers even on forums which in many cases involved extra efforts and time on the professor's behalf. In order to encourage and supplant the lack of human interaction between students, many of their assignments required group activities even on Zoom virtual rooms.

The Faculty of Business and Tourism's bachelor curriculum consists in a 3-year continuous formation that amounts on average studying 6 or 7 subjects per each semester and, if successfully finished, ends with the certification of a becoming a bachelor in Economics.

For the 2020 - 2021 academic year which was organized entirely via distance blended learning, The Faculty of Business and Tourism has counted a total of 490 students registered for native language 
learning whilst 64 chose the English program of Business Administration on Commerce, Tourism, Services, Commodity Science and Quality Management. As a result, the central desideratum of the project From university dropout to performance in Business and Tourism (PERFORM-BT) is to understand the difficulties encountered by students via distance learning and reduce the dropout rate and, for future students, proving real solutions for their needs such as coaching, support and remedial activities.

\subsection{Participants}

As previously mentioned, the survey's respondents were freshmen who during the 2020-2021 academic year have studied exclusively online by the means of the Blended Learning Platform and other communication online applications. Moreover, these respondents were also enrolled in activities provided via the PERFORM-BT program, making up for the target group we were addressing. The analysis might also be useful considering the specialization that respondents had during their secondary education formation. Their mathematic, economic or social science high-school profile might also represent a factor that contributes to finding online learning easy or difficult to accept or implement, the use of different platforms or interaction with peers and professors from a distance learning stance perceived as a smooth activity.

The accumulation of data was performed by using a descriptive method of research. The 41 responses were collected online from Business and Tourism freshmen during a 2 weeks period. According to our sample, in regards to their secondary formation specialization we have found the following:

- $27 \%$ of students were philology graduates;

- $18 \%$ have graduated from a tourism specialization;

- $18 \%$ have an economic background;

- $17 \%$ were mathematics and informatics graduates;

- $10 \%$ were commerce graduates;

- $10 \%$ other specializations (natural and social sciences).

Compared to prior generations that have enrolled to The Faculty of Business and Tourism, the 20202021 students have a more adequate formation, in accordance to the institution's curriculum and activities. Still, more than a quarter of our respondents represent a category whose high school profile was built based more on sociology rather than economic majors, therefore they still might encounter different challenges during their formation in regards to economic and mathematic-related subjects.

Considering a gender distribution of our respondents, $85.4 \%$ represent female undergraduates while $14.6 \%$ represent male. Moreover, while $34.1 \%$ of the respondents have come from Romania's rural area, $65.9 \%$ have urban origins. Based on prior research, we should also consider that a student's location and lack of accessibility to internet or transportation may constitute a prerequisite for encountering difficulties in the process of learning via online platforms, and, in many cases even dropout.

\subsection{Data collection and analysis}

We performed the present research with a main objective of understanding students' needs and difficulties into their online distance learning context in order to expedite better results in regards to remedial activities provided via the PERFORM-BT program. Also, by improving the process of education and the student-professor-university interrelation, we attempted to discover potential factors that might contribute to an increase rate of dropout after the first year from enrollment.

The subjects of our research were students who had difficulties via distance learning and were prone to a sudden stop of their education. Such students, after their first semester encountered problems at more than two disciplines (where they were not able to pass the exams over various reasons), they had a low high school GPA on their university admission or came from disadvantaged backgrounds (precarious education in rural area) or minorities. Based on the aforementioned criteria they were considered vulnerable students whose academic performance could be improved by taking part in various online activities provided through PERFORM-BT program. 
At the academic year opening, while signing their student contract, in order to be involved in activities provided by this program, vulnerable students who willingly wanted to participate had to give their informed written consent by signing an addendum. This procedure was taken in order to be GDPR compliant in a distance learning context. Moreover, to assure an optimal COVID-19 protection, all the Perform BT activities were planned to take place in a virtual space via online platforms, the same used for lectures or seminars, therefore being easily accessed by both students, teachers and other specialists. Also, by signing the addendum we were granted the permission to get continuous updates regarding a student's academic performance like their grading and situation (enrolled or dropped out after a semester). This way we secured the privacy of their personal data along with addressing the fact that they were able to take part to activities they cared for, in accordance to their preferences or needs. Also, if they were unable to address or identify these needs they were advised by teachers or other specialists in order to take the best decision for their academic and professional path. Subsequent to providing the required procedure, participants had the opportunity to take in the following activities:

- Remedial academic activities - students had the opportunity to take part in lectures or seminars in accordance to their needs, for subjects that they considered difficult to understand;

- Coaching - group or individual meetings for personal and academic development;

- Career tutoring - group or individual meetings for career guidance;

- Business and tourism workshops - virtual workshops with top specialists from renowned international companies or local entrepreneurs;

- Virtual visits to companies or small businesses.

The current research was mainly focused on the academic performance, students' needs, their difficulties in the process of online learning and the impact of remedial activities, if any, over their academic performance. Besides their difficulties we were interested to find out what is their opinion on distance learning versus class learning, what are the best platforms to be used for online learning, what solutions they can find in regards to online learning or factors that might lead to a dropout after their first year.

Based on their a priori consent we were able to create a target group, using the variables that defined our vulnerable student. After creating a group that met our criteria we sent an individual e-mail informing about the purpose of research via an online questionnaire which was also attached to the email. Students were asked to complete the survey during a 2 week time span, at the end of the second semester. All the answers were collected via online means by the use of Google Forms.

In order to get a student's honest opinion, we opted to implement a multiple choice close-ended survey where they could make an assessment regarding understanding a subjects' content, the main factors that lead to a difficult understanding (e.g. content, teaching style, the online platform used, timetable and many others) or what are the best solutions to improve such a situation (e.g. remedial activities, individual tutoring, less amount of theoretical notions, coaching on learning techniques and many others).

Moreover, from a descriptive statistics perspective, we were also interested in finding if, by the end of the second semester, students were likely to drop out of university and what were the factors that might determine such a decision (e.g. financial reasons, lack of time caused by a full-time job, feeling that choosing the faculty was an error). Also, considering that the entire academic year was held entirely online we were also interested to find out if they would like to continue on this format of distance learning or, if they would prefer the classical setting. In the same tone, we were curious to find if students prefer a synchronous, asynchronous or a mixed type of teaching process and what where the best most useful platforms.

The second part of the questionnaire was implemented via a five point Likert scale with different objectives. First, we were interested to find out freshmen' perception over potential disciplines that might create difficulties over their exam (e.g. Marketing, Macroeconomics, Management and others). Furthermore, we used a seven point Likert scale, where 1 represented an accessible subject and 7 a difficult discipline to understand, in order to create a hierarchy over the general perception of subjects' level of difficulty. Last, but probably one of the most important aspects of our research was finding out 
what is the utility of online instruments used in the teacher-student interaction (e.g. Discord, WhatsApp, Google Meet, Zoom Meeting, ASE Online Blended Learning Platform, Google Chat, Google Classroom, YouTube and Microsoft Teams). Moreover we were interested to get an assessment over the main factors that made online distance learning harder than expected (e.g. limited peer-to-peer interaction, limited student-professor interaction, poor quality of hardware, low internet connection and many others).

By the end of our two-weeks collection of responses via the online survey, the data was refined and analyzed with Microsoft Excel Software providing a big picture of the 2020-2021 second semester with the main objective of refining processes and operations on behalf of the teaching stuff and the university, having always in mind the best interest of the student.

\section{Results and discussions}

The survey started by trying to figure out what were the second semester's subjects that might lead to various difficulties into understanding a subject (mainly content) and, later on, that will translate into an inability of passing the exam. A five point Likert scale was used, where 1 represented "not at all" and 5 "to a very large extent", for every second semester subject included in the curriculum of the first academic year. Results obtained for this introductive part of the research are presented in Figure no.1.

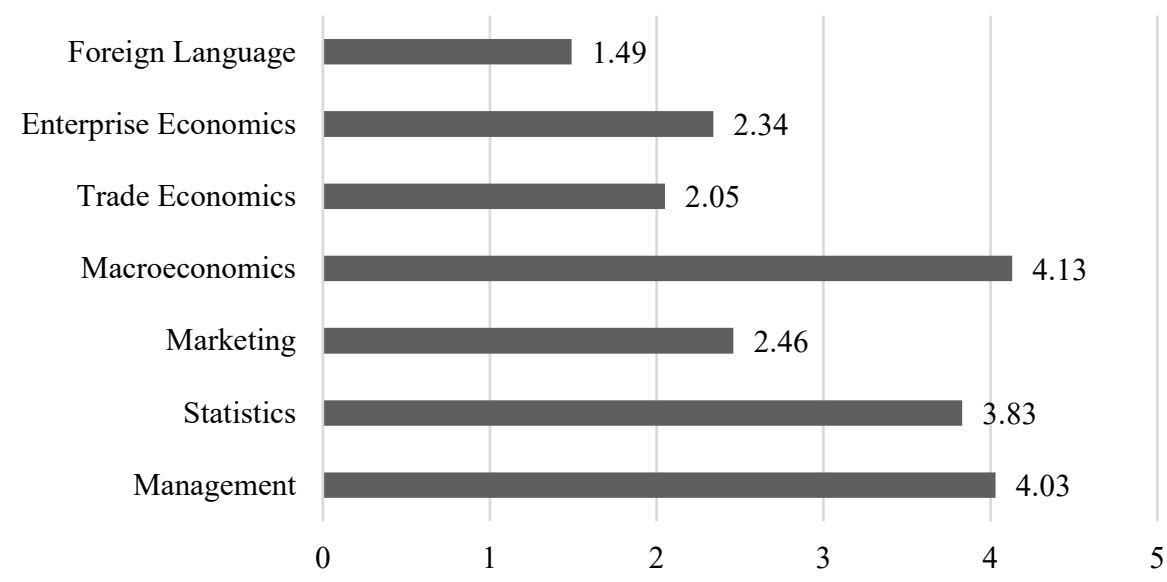

Fig. no. 1: Students' perception on the difficulty level of second semester subjects for future exams

Source: Authors, based on research

As far as our research has shown (Table no. 1), first year students reached the conclusion that, in their opinion, they might encounter the most exam problems in relation to subjects as Macroeconomics (4.13 - highest score), Management (score 4.03) and Statistics (score 3.83). On the other hand, disciplines such as Marketing, Enterprise Economics and Trade Economics are perceived as easier and, in relation to exams, they present students little to no difficulties. In the case of foreign languages, the surveyed students look at the exam as one that will not bring any obstacles at all.

Table no. 1: Difficulty into understanding a subject's content. Hierarchy of subjects for the first bachelor year, second semester

\begin{tabular}{|l|l|l|}
\hline Subject & Score & Ranking \\
\hline Management & 5.375 & 6 \\
\hline Statistics & 5.35 & 5 \\
\hline Marketing & 2.75 & 3 \\
\hline Macroeconomics & 5.575 & 7 \\
\hline Enterprise economics & 2.5 & 2 \\
\hline Trade economics & 2.825 & 4 \\
\hline Foreign language & 1.475 & 1 \\
\hline
\end{tabular}

Source: Authors, based on research 
The present research continued with a second question which consisted in obtaining a hierarchy of second semester subjects, based on their level of difficulty, regarded again by students. As a result, Macroeconomics was weighted as the one most difficult to understand (5,575 - the highest score), followed closely by Management and Statistics with a score of 5.35. As far as the results show, the data is highly correlated to prior findings from the first survey question. The other subjects such as Marketing and Trade Economics are regarded as having a low level of difficulty, while the easiest disciplines are Foreign Languages.

Table no. 2: Main determinants to an increasing rate of difficulty in learning: Lecture

\begin{tabular}{|l|c|c|c|c|c|c|c|}
\hline \multicolumn{1}{|c|}{ LECTURE } & Management & Statistics & Marketing & Macroeconomics & $\begin{array}{c}\text { Trade } \\
\text { economics }\end{array}$ & $\begin{array}{c}\text { Enterprise } \\
\text { economics }\end{array}$ & $\begin{array}{c}\text { Foreign } \\
\text { Language }\end{array}$ \\
\hline Factors & \multicolumn{5}{|c|}{ Percentage of the responses } \\
\hline $\begin{array}{l}\text { Teaching } \\
\text { method }\end{array}$ & $77.5 \%$ & $19.51 \%$ & $2.44 \%$ & $34.15 \%$ & $21.95 \%$ & $29.27 \%$ & $0.00 \%$ \\
\hline $\begin{array}{l}\text { Subject } \\
\text { contents }\end{array}$ & $37.5 \%$ & $65.85 \%$ & $9.76 \%$ & $41.46 \%$ & $9.76 \%$ & $9.76 \%$ & $2.44 \%$ \\
\hline $\begin{array}{l}\text { Amount } \\
\text { of information }\end{array}$ & $57.5 \%$ & $65.85 \%$ & $9.76 \%$ & $60.98 \%$ & $19.51 \%$ & $19.51 \%$ & $2.44 \%$ \\
\hline $\begin{array}{l}\text { Difficult } \\
\text { communication } \\
\text { with the } \\
\text { teacher }\end{array}$ & $70 \%$ & $4.88 \%$ & $0.00 \%$ & $31.71 \%$ & $21.95 \%$ & $9.76 \%$ & $0.00 \%$ \\
\hline $\begin{array}{l}\text { The time at } \\
\text { which the } \\
\text { activity is } \\
\text { scheduled }\end{array}$ & $30 \%$ & $26.83 \%$ & $14.63 \%$ & $21.95 \%$ & $19.51 \%$ & $12.20 \%$ & $4.88 \%$ \\
\hline $\begin{array}{l}\text { The online } \\
\text { channel used } \\
\text { for the activity }\end{array}$ & $10 \%$ & $24.39 \%$ & $7.32 \%$ & $12.20 \%$ & $4.88 \%$ & $9.76 \%$ & $12.20 \%$ \\
\hline $\begin{array}{l}\text { Assessment } \\
\text { requirements }\end{array}$ & $47.5 \%$ & $17.07 \%$ & $2.44 \%$ & $36.59 \%$ & $14.63 \%$ & $4.88 \%$ & $0.00 \%$ \\
\hline $\begin{array}{l}\text { Lack of prior } \\
\text { knowledge of } \\
\text { the subject }\end{array}$ & $52.5 \%$ & $60.98 \%$ & $29.27 \%$ & $31.71 \%$ & $24.39 \%$ & $31.71 \%$ & $2.44 \%$ \\
\hline
\end{tabular}

Source: Authors, based on research

Furthermore, we were interested into finding out what are the main contributors to an increased rate of difficult understanding of disciplines, both in the case of a lecture or a seminar. Students were offered the opportunity to express their thoughts through a multiple choice questionnaire, considering several factors that we also discovered in previous research (Table no. 2). In the case of the most difficult subject, Macroeconomics, our respondents consider that the factor with the greatest negative impact over their perception is represented by the huge amount of information that needs to be absorbed in a matter of weeks and its content. The same situation can be found in relation to Statistics. Instead, for the second most difficult discipline, Management, the surveyed students consider that the factor with the greatest impact in this regard is the teaching method, a difficult communication to the professor, the amount of information to be assimilated and lack of prior knowledge. On the other side, coherence towards an answer is proved once again by the fact that, in the case of the Foreign Languages (considered the easiest), there were rare situations in which factors such as the online channel used represented minor contributors to a negative perspective towards the level of understanding.

In the case of seminars (Table no. 3), studying Macroeconomics involved a difficulty related to the whole volume of information that must be assimilated, followed by the content of the discipline. Once again, a relatively similar situation is encountered towards Statistics, where, however, a difficult professor-student communication has a lesser influence than in the case of the Macroeconomics. The subject of Management involves again problems regarding the teaching method, communication, and the volume of information in relation to the semester evaluation requirements. 
Table no. 3: Main determinants to an increasing rate of difficulty in learning: Seminar

\begin{tabular}{|c|c|c|c|c|c|c|c|}
\hline LECTURE & Management & Statistics & Marketing & Macroeconomics & $\begin{array}{c}\text { Trade } \\
\text { economics }\end{array}$ & $\begin{array}{l}\text { Enterprise } \\
\text { economics }\end{array}$ & $\begin{array}{c}\text { Foreign } \\
\text { Language }\end{array}$ \\
\hline Factors & \multicolumn{7}{|c|}{ Percentage of the responses } \\
\hline $\begin{array}{l}\text { Teaching } \\
\text { method }\end{array}$ & $70 \%$ & $17.07 \%$ & $2.44 \%$ & $26.83 \%$ & $19.51 \%$ & $26.83 \%$ & $0.00 \%$ \\
\hline \begin{tabular}{|l|} 
Subject \\
contents
\end{tabular} & $42.5 \%$ & $65.85 \%$ & $12.20 \%$ & $56.10 \%$ & $12.20 \%$ & $12.20 \%$ & $2.44 \%$ \\
\hline $\begin{array}{l}\text { Amount of } \\
\text { information }\end{array}$ & $50 \%$ & $65.85 \%$ & $19.51 \%$ & $58.54 \%$ & $21.95 \%$ & $24.39 \%$ & $4.88 \%$ \\
\hline $\begin{array}{l}\text { Difficult } \\
\text { communication } \\
\text { with the } \\
\text { teacher } \\
\end{array}$ & $60 \%$ & $9.76 \%$ & $2.44 \%$ & $31.71 \%$ & $24.39 \%$ & $12.20 \%$ & $4.88 \%$ \\
\hline $\begin{array}{l}\text { The time at } \\
\text { which the } \\
\text { activity is } \\
\text { scheduled }\end{array}$ & $37.5 \%$ & $31.71 \%$ & $21.95 \%$ & $39.02 \%$ & $12.20 \%$ & $14.63 \%$ & $2.44 \%$ \\
\hline $\begin{array}{l}\text { The online } \\
\text { channel used } \\
\text { for the activity }\end{array}$ & $10 \%$ & $17.07 \%$ & $14.63 \%$ & $9.76 \%$ & $7.32 \%$ & $9.76 \%$ & $2.44 \%$ \\
\hline $\begin{array}{l}\text { Assessment } \\
\text { requirements }\end{array}$ & $50 \%$ & $24.39 \%$ & $7.32 \%$ & $41.46 \%$ & $9.76 \%$ & $7.32 \%$ & $9.76 \%$ \\
\hline $\begin{array}{l}\text { Lack of prior } \\
\text { knowledge of } \\
\text { the subject }\end{array}$ & $42 \%$ & $58.54 \%$ & $17.07 \%$ & $36.59 \%$ & $21.95 \%$ & $24.39 \%$ & $2.44 \%$ \\
\hline
\end{tabular}

Source: Authors, based on research

Moreover, by the means of the current survey, we aimed at identifying students' perception regarding the opportune measures to alleviate difficulties encountered into understanding second semester subjects and increase students' academic performance (Table no.4). In the case of the most difficult discipline, Macroeconomics, the preferred solution was introducing a program of consultations apart from scheduled classes /seminars and extra courses or seminars, which means that organizing remedial activities might be a good solution for the current subject. A similar situation was found in regards to Statistics, a case where remedial activities were held during the second semester. On the other side, Management was the subject where the application of different teaching methods, advice on effective study methods and techniques or recovery courses / seminars were considered appropriate measure by the students.

Table no. 4: Solutions for an increased performance rate and better understanding of subjects

\begin{tabular}{|l|c|c|c|c|c|c|c|}
\hline \multicolumn{1}{|c|}{ Solutions } & Management & Statistics & Marketing & Macroeconomics & $\begin{array}{c}\text { Trade } \\
\text { economics }\end{array}$ & $\begin{array}{c}\text { Enterprise } \\
\text { economics }\end{array}$ & $\begin{array}{c}\text { Foreign } \\
\text { Language }\end{array}$ \\
\hline $\begin{array}{l}\text { Consulting hours, } \\
\text { besides the } \\
\text { scheduled lectures } \\
\text { and seminars }\end{array}$ & $57.5 \%$ & $56.10 \%$ & $12.20 \%$ & $82.93 \%$ & $21.95 \%$ & $17.07 \%$ & $2.44 \%$ \\
\hline $\begin{array}{l}\text { Different teaching } \\
\text { methods }\end{array}$ & $75 \%$ & $26.83 \%$ & $7.32 \%$ & $39.02 \%$ & $24.39 \%$ & $21.95 \%$ & $2.44 \%$ \\
\hline $\begin{array}{l}\text { Smaller } \\
\text { information } \\
\text { volume }\end{array}$ & $50 \%$ & $56.10 \%$ & $12.20 \%$ & $53.66 \%$ & $21.95 \%$ & $21.95 \%$ & $4.88 \%$ \\
\hline $\begin{array}{l}\text { Supplementary } \\
\text { lectures/seminars, } \\
\text { tutoring classes }\end{array}$ & $60 \%$ & $65.85 \%$ & $14.63 \%$ & $73.17 \%$ & $9.76 \%$ & $7.32 \%$ & $4.88 \%$ \\
\hline $\begin{array}{l}\text { Advice on effective } \\
\text { study methods and } \\
\text { techniques }\end{array}$ & $75 \%$ & $51.22 \%$ & $41.46 \%$ & $70.73 \%$ & $26.83 \%$ & $31.71 \%$ & $17.07 \%$ \\
\hline
\end{tabular}

Source: Authors, based on research 
The present research also aimed at finding a comparative analysis of difficulty between the second and first semester subjects (Figure no.2).

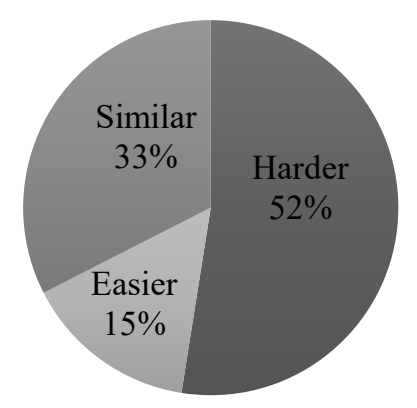

Fig. no. 2: Subjects' level of difficulty: Second Semester vs. First Semester Source: Authors, based on research

As a result, more than half of the students surveyed (52\%) consider that subjects studied in the second semester are more difficult than those in the first semester, a third (33\%) consider that they have the same level of difficulty, while $15 \%$ consider that they are even easier, probably in terms of adaptation to their academic life.

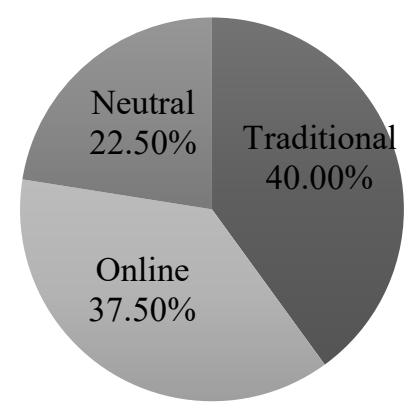

Fig. no. 3: Online distance learning vs. Traditional learning

Source: Authors, based on research

Considering the measures taken to prevent the spread of Covid-19, the aim of the research was also to identify students' opinion regarding The Bucharest University of Economic Studies decision to carry out teaching activities in an online setup (online.ase.ro platform and other means used by professors). In this regard, $40 \%$ of students mentioned that they would have preferred the activity to take place face to face, on campus, while $37.5 \%$ agreed to study online (Figure no.3). It is noteworthy that the percentage of those who accept remote learning, to the detriment of the face to face learning, has increased, compared to prior research conducted in the first semester of 2020-2021 academic year (where 71.11\% of students mentioned that they would prefer for the activity to take place on a traditional framework).

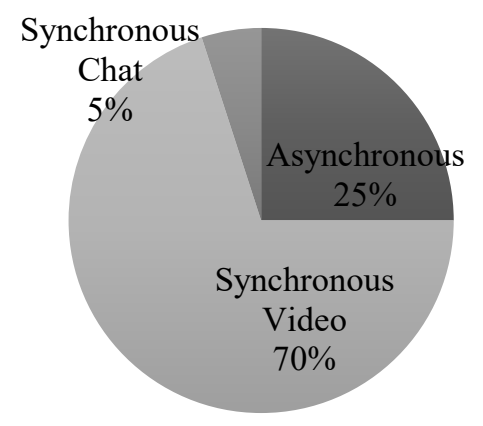

Fig. no. 4: Preferences regarding online distance learning methods

Source: Authors, based on research 
From the perspective of conducting teaching activities online (Figure no.4), an overwhelming proportion of students surveyed $(70 \%)$ mentioned that they prefer synchronous teaching on video platforms (e.g.: Zoom, Google Meet, Microsoft Teams), while 25\% expressed the option to asynchronous teaching (posting teaching materials on the online.ase.ro platform, etc.). It is noteworthy that, compared to firstsemester responses, the proportion of those who prefer asynchronous teaching, to the detriment of live, on video platforms has increased.

Also from the perspective of online distance learning (Figure no. 5), we aimed at identifying students' perception regarding the most useful tools that can be implemented in education. Therefore, Zoom Meetings is considered to be the most useful application (score 4.775) on a scale from 1 "useless" to 5 "very useful", followed by the Blended Learning Platform of the university (score 4.4) and WhatsApp (score 4.05). It is noted that the perceived utility of the Blended Learning platform has increased, compared to the first semester, probably in terms of experience. The least useful applications are the Google Chat and Microsoft Teams tools. These responses or students' preferences were taken into consideration in establishing the working methodologies within the remedial activities.

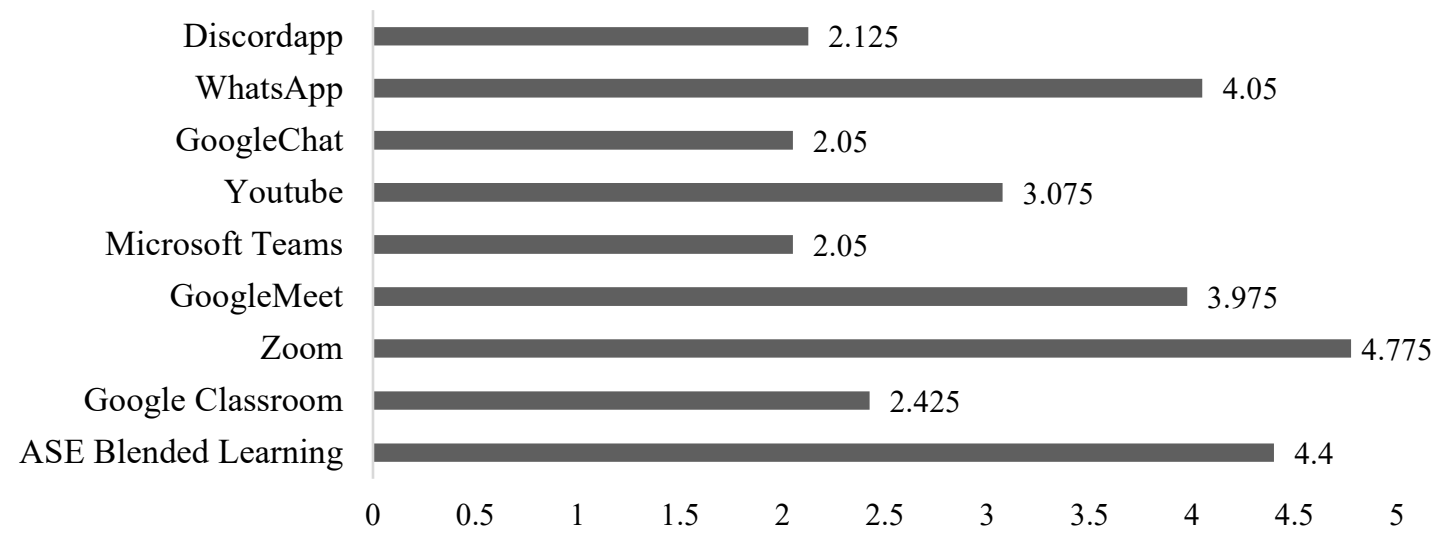

Fig. no. 5: Students' preferences regarding online applications utility Source: Authors, based on research

The survey also sought to obtain a broad image on issues that might hinder the learning process in an online environment. According to their responses, students do not encounter major difficulties due to any factor. However, insufficient interaction with teachers has a relatively large influence (score 3.3 on a scale from 1 "not at all" to 5 "to a very large extent"), while poor internet connection and insufficient interaction with colleagues also have some impact (score 2.475 and 2.4, respectively). The conditions related to the lack of infrastructure (access to equipment or utilities or their quality) do not impose difficulties in the learning process.

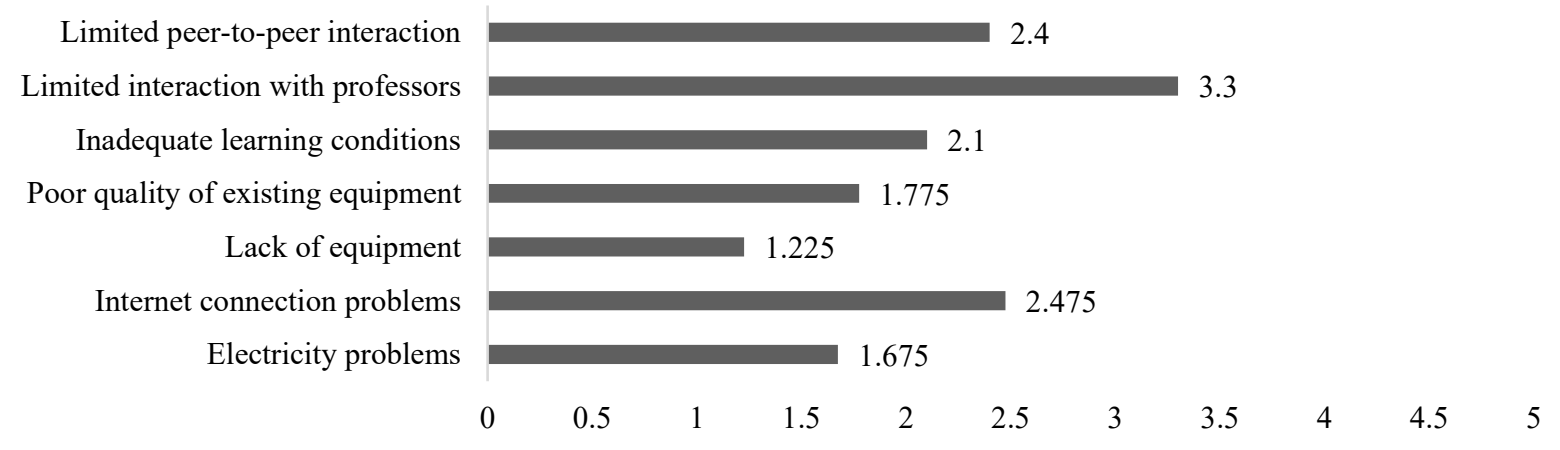

Fig. no. 6: Factors that make online learning more difficult Source: Authors, based on research 
The survey also aimed at identifying to a specific extent which students considered dropping out of university courses. Thus, only $22 \%$ of those surveyed took this into account, while $78 \%$ were interested into continuing their formation.

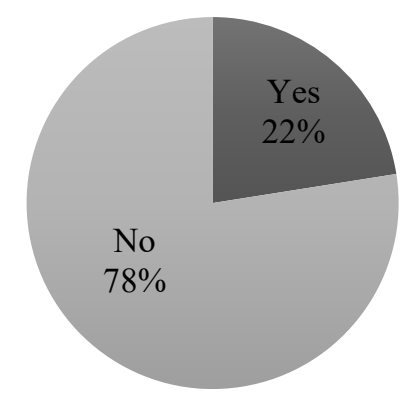

Fig. no. 7: Students' intention into dropping out of university

Source: Authors, based on research

Half of the students surveyed mentioned that they would consider dropping out of university if they encountered difficulties in passing the exams, which proves once again the usefulness of remedial activities. In addition, $20 \%$ would weigh the decision to continue their studies if they were unable to balance the study program with their job.

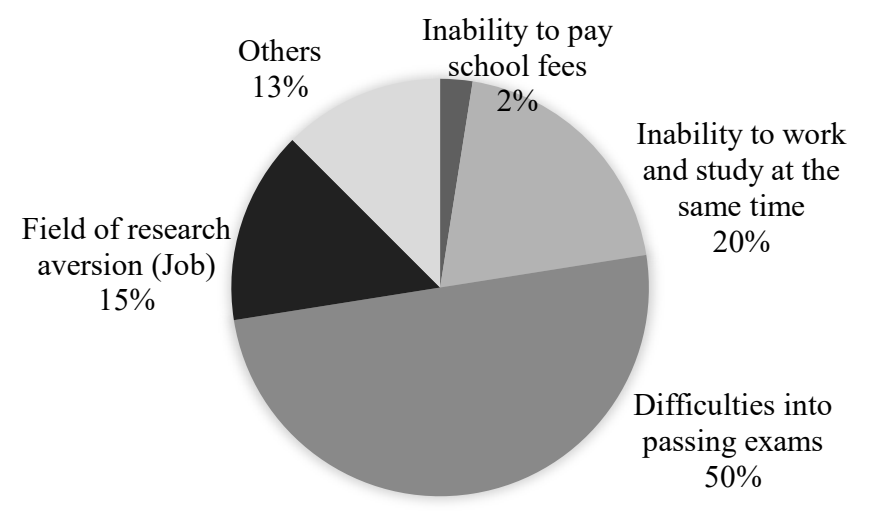

Fig. no. 8: Factors that may lead to university drop out

Source: Authors, based on research

\section{Conclusions}

Investigating students' difficulties in relation to online distance learning encountered at The Bucharest University of Economic Studies, The Faculty of Business and Tourism, is essential in the context of reducing the dropout rate and increasing their academic performance and interests. Therefore, listening and understanding students' needs is essential in an open relationship between students, professors and the faculty as a mediator in the process of education. Also, by the means of this research we were able to find out their perspective in order to create new strategies, methodologies of teaching and ways of interacting between the stakeholders of this relation. As in a traditional setup, on campus, open communication will always provide a better understanding of needs and an innovative way of providing feasible solutions. Of course, the research has many limitations, nonetheless, it should be conducted at the end of every academic year, not only in the case of first-year students, but on every academic year, in the case of both bachelor and masters studies.

\section{Acknowledgement}

This present research was presented as a result of the activity conducted in the project „De la abandonul universitar la performanţă în Business şi Turism (Perform-BT)" - PROIECTUL PRIVIND ÎNVĂȚĂMÂNTUL SECUNDAR (ROSE), Acord de grant nr. 174 /SGU/NC/II din 10.09.2019. 


\section{References}

Amir, L.R., Tanti, I., Maharani, D.A. et al. 2020. Student perspective of classroom and distance learning during COVID-19 pandemic in the undergraduate dental study program Universitas Indonesia. BMC Medical Education, 20 (392), DOI: 10.1186/s12909-020-02312-0.

Babatunde Adedoyin, O., Soykan, E. 2020. Covid-19 pandemic and online learning: the challenges and opportunities, Interactive Learning Environments, DOI: 10.1080/10494820.2020.1813180.

Bao, W. 2020. COVID-19 and online teaching in higher education: A case study of Peking University. Human Behavior and Emerging Technologies, 2(2), pp. 113-115.

Bennett, S., Maton, K., \& Kervin, L. 2008. The 'digital natives' debate: A critical review of the evidence. British Journal of Educational Technology, 39(5), pp. 775-786.

Bojovic, Z., Bojovic, P. D., Vujosevic, D., \& Suh, J. (2020). Education in times of crisis: Rapid transition to distance learning. Computer Applications in Engineering Education, 28, pp. 1467-1489.

Cao, W., Fang, Z., Hou, G., Han, M., Xu, X., Dong, J., \& Zheng, J. 2020. The psychological impact of the COVID19 epidemic on college students in China. Psychiatry Research, 287, 112934.

Carroll, N., \& Conboy, K. 2020. Normalising the "new normal": Changing tech-driven work practices under pandemic time pressure. International Journal of Information Management, 55, 102186.

Chakraborty P, Mittal P, Gupta MS, Yadav S, Arora A. 2021. Opinion of students on online education during the COVID-19 pandemic. Human Behavior and Emerging Technologies, 3, pp. 357-365.

Dhawan, S. 2020. Online learning: A panacea in the time of COVID-19 crisis. Journal of Educational Technology Systems, 49(1), pp. 5-22.

Di Pietro, G., Biagi, F., Costa, P., Karpiński Z., Mazza, J, 2020, The likely impact of COVID-19 on education: Reflections based on the existing literature and international datasets, EUR 30275 EN, Publications Office of the European Union, Luxembourg.

Edelhauser E, Lupu-Dima L. 2020. Is Romania Prepared for eLearning during the COVID-19 Pandemic? Sustainability. 2020; 12(13): 5438.

Feldman, J. 2020. To Grade or Not to Grade? Available at: https://www.ascd.org/el/articles/to-grade-or-not-tograde, [Accesed 01 June 2021].

Garrison, D.R., Kanuka, H. 2004. Blended learning: uncovering its transformative potential in higher education. The Internet and Higher Education, 7, pp. 95-105.

Hodges, C., Moore, S., Lockee, B., Trust, T., \& Bond, A. 2020. The difference between emergency remote teaching and online learning. Educause Review, Available at: https://er.educause.edu/articles/2020/3/thedifferencebetween-emergency-remote-teaching-and-online-learning, [Accesed 15 July 2021],

Huang, C., Wang, Y., Li, X., Ren, L., Zhao, J., Hu, Y., Zhang, L., Fan, G., Xu, J., Gu, X., \& Cheng, Z. 2020. Clinical features of patients infected with 2019 novel coronavirus in Wuhan, China. The Lancet, 395(10223), pp. 497-506.

Jæger, M. M., \& Blaabæk, E. H. 2020. Inequality in learning opportunities during Covid-19: Evidence from library takeout. Research in Social Stratification and Mobility, 68, 100524.

Kopp, M., Gröblinger, O., \& Adams, S. 2019. Five common assumptions that prevent digital transformation at higher education institutions. INTED 2019 Proceedings, pp. 1448-1457.

Nash, C. 2020. Report on digital literacy in academic meetings during the 2020 COVID-19 lockdown. Challenges, $11(2), 20$.

OECD. 2020. Education and COVID-19: Focusing on the long-term impact of school closures. Available at: https://read.oecd-ilibrary.org/view/?ref=135_135187-1piyg9kc7w\&title=Education-and-COVID-19Focusing-on-the-long-term-impact-of-school-closures, [Accesed 01 June 2021].

Patricia, A. 2020. College students' use and acceptance of emergency online learning due to COVID-19. International Journal of Educational Research Open, DOI: 10.1016/j.ijedro.2020.100011.

Pei L, Wu H. 2019. Does online learning work better than offline learning in undergraduate medical education? A systematic review and meta-analysis. Medical Education Online. 24(1), DOI: 10.1080/10872981.2019.1666538. 
Peters, M. A., Wang, H., Ogunniran, M. O., Huang, Y., Green, B., Chunga, J. O. Khomera, S. W. 2020. China's internationalized higher education during COVID-19: Collective student autoethnography, Postdigital Science and Education, 2(3), pp. 968-988.

Poon, J. 2013. An examination of a blended learning approach in the teaching of economics to property and construction students, Property Management, 31(1), pp. 39-54.

Paules, C. I., Marston, H. D., \& Fauci, A. S. 2020. Coronavirus infections - more than just the common cold. Jama, 323(8), pp. 707-708.

Prensky, M. 2001. Digital natives, digital immigrants. On the Horizon, 9(5), DOI: 10..1108/10748120110424816.

Ribeiro, R. 2020. How university faculty embraced the remote learning shift. EdTech Magazine. Available at: https://edtechmagazine.com/higher/article/2020/04/how-university-faculty-embraced-remote-learningshift, [Accesed 01 June 2021].

Shariman, T. P. N. T., Razak, N. A., \& Noor, N. F. M. 2012. Digital literacy competence for academic needs: An analysis of Malaysian students in three universities. Procedia-Social and Behavioral Sciences, 69(1), pp. 1489-1496.

Strielkowski, W. 2020. COVID-19 pandemic and the digital revolution in academia and higher education. Preprints, 2020040290. Available at: http://doi.org/10.20944/preprints202004.0290.v1, [Accesed 01 July 2021].

Toprak, M., Bayraktar, Y., Yorgun, S. and Ayfer Ozyilmaz, A., 2021. Digital Transformation, Research University and Restructuring of Higher Education: A Model Proposal for Istanbul University Faculty of Economics, Journal of Economy Culture and Society, 63(63), pp. 67-92.

UNESCO. 2020a. COVID-19 Educational Disruption and Response. Available at: https://en.unesco.org/covid19/educationresponse, [Accesed 01 June 2021].

Viner, R. M., Russell, S., Croker, H., Packer, J., Ward, J., Stansfield, C., Mytton, O., Bonell, C., Booy, R. 2020. School Closure and Management Practices During Coronavirus Outbreak Including COVID-19: A rapid systematic review Available at: https:/www.thelancet.com/journals/lanchi/article/PIIS-30095)20(46422352X/fulltext26, [Accesed 01 July 2021].

World Health Organization. 2020. Available at: https://www.who.int/dg/speeches/detail/who-director-general-sopening-remarks-at-the-media-briefing-on-covid-19\%2D\%2D-11-march-2020, [Accesed 02 July 2021].

Zhang, W., Wang, Y., Yang, L., \& Wang, C. 2020. Suspending classes without stopping learning: China's education emergency management policy in the COVID-19 outbreak. Journal of Risk and Financial Management, 13(3), 55.

Zogas S, Kolokathi A, Birbas K, Chondrocoukis G, Mantas J. 2016. The e-Learning Effectiveness versus Traditional Learning on a Health Informatics Laboratory Course. Studies in Health Technology and Informatics, 226, pp. 109-112. 